\title{
Breast cancer screening knowledge among Hungarian women: a cross-sectional study
}

Diána Reményi Kissné ${ }^{1}$ Noémi Gede ${ }^{2^{*}}$, Zsolt Szakács ${ }^{2,3}$ and István Kiss ${ }^{4}$

\begin{abstract}
Background: Breast cancer (BC) is the leading malignant tumor among women worldwide. Although attending regular BC screening effectively reduces cancer-related mortality, surveys testify that screening knowledge is critically low among women. We aimed to conduct a comparative cross-sectional survey to assess BC and BC screening-related knowledge in Hungary.

Methods: Women between 25 and 65 years of age without a previous history of malignant tumors were included with non-probability sampling in 2017. Respondents were recruited either from primary care (laywomen) or from the waiting rooms of mammography (screening attendees). A self-completion questionnaire was constructed with questions about BC (risk factors, signs and symptoms, curability, and mortality), BC screening (mammography and breast self-examination), and BC-related information sources to assess knowledge among laywomen and screening attendees. In addition to descriptive statistics, odds ratios with 95\% confidence intervals were calculated in univariate analysis and logistic regression was used in multivariate analysis.

Results: Altogether, 480 women completed the questionnaire, of which 429 (227 laywomen and 202 screening attendees) were eligible for inclusion. Laywomen and screening attendees knew the recommended age at first mammography in $35.2 \%$ and $86.6 \%$, the recommended frequency of screening in $33.9 \%$ and $12.9 \%$, the recommended age at first breast-self examination in $38.8 \%$ and $51.2 \%$, had sufficient knowledge of the risk factors of BC in $7.0 \%$ and $5.9 \%$, and that of signs and symptoms of $B C$ in $16.7 \%$ and $28.9 \%$, respectively. A higher proportion of screening attendees correctly identified the recommended age of first BC screening correctly than that of laywomen $(86.6 \%$ vs. $35.2 \%$; $p<0.001$ ). The most popular information sources were television among laywomen and general practitioners or specialists among screening attendees. In multivariate analysis, older age, higher education, and place of residency were significant predictors of the right answers.
\end{abstract}

Conclusions: Although knowledge was insufficient in almost all fields of the questionnaire, the most prominent gap was observed concerning risk factors and signs and symptoms of BC both in laywomen and, unexpectedly, screening attendees. Most laywomen were lacking knowledge of screening protocol. These results urge breast health and BC knowledge interventions in Hungary.

Keywords: Breast cancer screening, Knowledge, Mammography

*Correspondence: gede.noemi@gmail.com

${ }^{2}$ Institute for Translational Medicine, Medical School, University of Pécs,

Szigeti út 12., 7624 Pecs, Hungary

Full list of author information is available at the end of the article

\section{Background}

Breast cancer $(\mathrm{BC})$ was a leading malignant tumor regarding incidence, prevalence, and mortality among women worldwide as well as in Europe in 2018. Worldwide incidence of female $\mathrm{BC}$ was 2 million while $\mathrm{BC}$ 
was responsible for more than 0.6 million fatalities in 2018. Within Europe, BC incidence was 522,513 with more than $137,707 \mathrm{BC}$-related fatalities in 2018 [1]. In Hungary, annual BC incidence has been exceeding 8000 cases since 2015 and reached 8215 with a mortality of 2212 in 2018 [2]. Data testified that Hungary is considerably behind the EU average concerning standardized mortality ratio of $\mathrm{BC}$ in 2018 [1].

$\mathrm{BC}$ is a multifactorial disease with complex pathomechanisms. Risk factors of $\mathrm{BC}$ include but are not limited to positive medical history for conditions or disorders in obstetrics, gynecology, reproduction, and endocrinology. Age is deemed to be an independent risk factor of BC. Besides, the cumulative number of periods seems to be important, which supports the central role of endogenous estrogen in the pathogenesis. Risk of BC doubles in cases where the first delivery is later than 30 years of age [3]. Additional modifiable risk factors involve the exposure to certain exogenous hormones (e.g., postmenopausal hormone therapy applied frequently to relieve the undesired changes of menopause) [4], smoking [5], high-fat diet [6], being overweight or obese, sedentary lifestyle, alcohol consumption (more than 1-2 drinks daily), high socioeconomic status, oral contraceptives containing estrogen, progestagen, or their derivatives; and vitamin D deficiency [4]. Chest irradiation carries a delayed, 7- to 17-fold risk of $\mathrm{BC}$ [7-9]. Protective factors include suckling: 12-month breastfeeding reduces the risk of pre-menopausal BC by $4 \%$ [10]. Genetics may account for $5-10 \%$ of $B C$ cases, of which even $30 \%$ may have BRCA 1 or BRCA 2 mutations [11]. These mutations increase the risk of $\mathrm{BC}$ tenfold, although several other genes (the so-called 'BC genes') have been implicated as contributors to the pathogenesis [12] Hereditary syndromes, e.g., Li-Fraumeni [13] and Cowden syndromes carry a high risk of BC [14].

A potential approach to coping with high $\mathrm{BC}$-related mortality is the introduction of $\mathrm{BC}$ screening programs. Studies proved that $\mathrm{BC}$ public health interventions promote early detection. Screening uptake of at least 70\% of the target population reduces $\mathrm{BC}$-related mortality significantly [15]. Although mammography reduces BCrelated mortality by a remarkable $25 \%$ among women between 50 and 69 years of age, the risk reduction is less prominent in younger women between 40 and 49 years of age [16]. On the contrary, studies recorded a humble 15\% decrease in BC-related mortality with frequent overdiagnosis (30\%) and, consequently, frequent overtreatment [17]. The success of BC screening can be attributed to early detection because the immediate removal of tumors with a diameter $<10 \mathrm{~mm}$ results in an average survival of 20 years in approximately $90 \%$ of the cases [18].
Mass screening for $\mathrm{BC}$ had been incorporated into public health services in Hungary in 2001 [15]. The target population of $\mathrm{BC}$ screening involves asymptomatic women between 45 and 65 years of age who are regularly invited to participate in screening with X-ray mammography once every two years $[19,20]$. Hungarian data from 2015 revealed that invitation for BC screening reaches $78.5 \%$ of the target population. Digital mammography accounted for $60 \%$ of cases. These quality indicators are far behind the $2015 \mathrm{EU}$ average [20].

There was not a comprehensive report which assessed women's knowledge of the field in Hungary, while insufficient knowledge may contribute to the suboptimal screening attendance rate. This inspired us to assess the knowledge of $\mathrm{BC}$ and $\mathrm{BC}$ screening among Hungarian women. In addition, we aimed to explore which channels are used by women to gather relevant information.

\section{Methods}

The study is reported following the STROBE Statement.

\section{Study design and settings}

This study is a cross-sectional survey. Subjects were recruited from 12 general practitioner clinics and the outpatient Department of Radiology, University of Pécs, Medical School, Hungary. Recruitment period lasted from March 2017 to June 2017.

\section{Sample}

We recruited a total of 480 women aged between 25 and 65 years with non-probability sampling (this age interval was the inclusion criteria). Missing data resulted in the exclusion of 52 women. Finally, data of 428 women (89.1\%) with complete dataset were eligible for the analysis. The study population was divided into two groups by site of recruitment: 227 women were recruited from primary care (laywomen) and another 201 from the waiting rooms of mammography of the Department of Radiology (screening attendees). The exculsion critera was the history of malignant tumors.

\section{Questionnaire development and validation}

We constructed a self-completion questionnaire. As the first step of production, our team of epidemiologists indicated the main areas of interest and phrased index questions accordingly. Then, the set of questions was revised by an oncologist to validate the medical content. Laypeople appraised the wording of questions. The English-language version of the questionnaire is provided in Appendix as Additional file.

The first set included 7 questions concerning sociodemography (sex, age, place of residence, marital status, education, financial situation, and religion). Followed 
by a set of 16 questions regarding knowledge of $\mathrm{BC}$ and $\mathrm{BC}$ screening, including multiple-choice questions about information sources. There were 2 multiple and 14 single choice questions given. In terms of signs and symptoms of $\mathrm{BC}$, respondents indicating correctly at least 5 options of the 8 given (all options were true) were considered to have sufficient knowledge. In terms of risk factors of $\mathrm{BC}$, respondents indicating correctly at least 2 options and incorrectly maximum 1 option of 21 given (13 and 12 were true in the groups of screening attendees and lay women, respectively) were considered to have sufficient knowledge.

Medical assistants distributed the questionnaire and obtained signed informed consent from participants. We secured anonymity of participants by linking informed consents to the corresponding questionnaires with a numeric code. Documents were kept in locked cabinets separately until processing.

\section{Statistical analysis}

We performed descriptive statistics including the calculation of central tendencies (means or medians) with the measure of dispersion and relative frequencies. In univariate analysis, we used the Mann-Whitney U-test to examine the association between the level of education and knowledge of the risk factors of $\mathrm{BC}$. We used the $X^{2}$ test with $\mathrm{Z}$ test to reveal the association between participation in screening and knowledge of timing of $\mathrm{BC}$ screening. In multivariate analysis, we used logistic regression with a probability of $95 \%$ with explanatory variables including age, education, and place of residency to examine the association between the sociodemographic characteristics and the dichotomous outcomes. Data were analyzed using SPSS 20.0 statistical software.

\section{Results}

Baseline sociodemographic characteristics of the study population are summarized in Table 1. Main findings are summarized in Table 2.

\section{Timing of BC screening}

A higher proportion of screening attendees correctly identified the recommended age of first $\mathrm{BC}$ screening correctly (that is, 45 years of age in Hungary) than that of laywomen $(35.2 \%$ vs. $86.6 \%$; $p<0.001)$.

The recommended frequency of $\mathrm{BC}$ screening in average-risk women (that is, once every 2 years in Hungary) was identified correctly in $33.9 \%$ and $12.9 \%$ by laywomen and screening attendees, respectively. Comparing screening attendees to laywomen of screening age not attending $\mathrm{BC}$ screening in the past 2 years did not reveal a significant difference between groups. Respondents who knew both the recommended age of first $\mathrm{BC}$ screening and the
Table 1 Sociodemographic characteristics of the groups

\begin{tabular}{|c|c|c|}
\hline Variable & $\begin{array}{l}\text { Laywomen } \\
\left(\mathrm{N}^{0}=227\right)\end{array}$ & $\begin{array}{l}\text { Screening attendees } \\
\left(\mathrm{N}^{0}=202\right)\end{array}$ \\
\hline Age (mean) & 47.22 & 53.33 \\
\hline (median) & 48.00 & 55.00 \\
\hline (minimum) & 25.00 & 31.00 \\
\hline (maximum) & 64.00 & 64.00 \\
\hline \multicolumn{3}{|l|}{ Place of residence $\left(\mathrm{N}^{0}, \%\right)$} \\
\hline City town & $117(51.5 \%)$ & $58(28.9 \%)$ \\
\hline Town & $56(24.7 \%)$ & $74(36.8 \%)$ \\
\hline Village & $54(23.8 \%)$ & $69(34.3 \%)$ \\
\hline \multicolumn{3}{|l|}{ Marital status $\left(\mathrm{N}^{0}, \%\right)$} \\
\hline Unmarried & $23(10.1 \%)$ & $13(6.5 \%)$ \\
\hline Married/common-law marriage & $136(59.9 \%)$ & $145(72.1 \%)$ \\
\hline Divorced/separated & $47(20.7 \%)$ & $23(11.4 \%)$ \\
\hline Widowed & $21(9.3 \%)$ & $20(10 \%)$ \\
\hline \multicolumn{3}{|l|}{$\begin{array}{l}\text { The highest level of education } \\
\left(N^{0}, \%\right)\end{array}$} \\
\hline Less than primary school & $2(0.9 \%)$ & $1(0.5 \%)$ \\
\hline Primary school & $24(10.6 \%)$ & $18(9 \%)$ \\
\hline Vocational or industrial school & $53(23.3 \%)$ & $43(21.4 \%)$ \\
\hline Secondary school & $50(22.0 \%)$ & $81(40.3 \%)$ \\
\hline College or university & $98(43.2 \%)$ & $58(28.9 \%)$ \\
\hline \multicolumn{3}{|l|}{ Health education $\left(\mathrm{N}^{0}, \%\right)$} \\
\hline Yes & $140(61.7 \%)$ & $148(73.6 \%)$ \\
\hline No & $87(38.3 \%)$ & $53(26.4 \%)$ \\
\hline \multicolumn{3}{|l|}{ Religiosity ( $\left.N^{0}, \%\right)$} \\
\hline Yes & $102(44.9 \%)$ & $113(56.2 \%)$ \\
\hline No & $125(55.1 \%)$ & $88(43.8 \%)$ \\
\hline \multicolumn{3}{|l|}{ Employment status ( $\left.\mathrm{N}^{0}, \%\right)$} \\
\hline Employed & $145(63.9 \%)$ & $119(59.2 \%)$ \\
\hline Unemployed & $7(3.1 \%)$ & $4(2.0 \%)$ \\
\hline Inactive & $66(29.0 \%)$ & $73(36.3 \%)$ \\
\hline Dependant & $9(4.0 \%)$ & $5(2.5 \%)$ \\
\hline \multicolumn{3}{|l|}{ Financial situation $\left(\mathrm{N}^{0}, \%\right)$} \\
\hline Very bad & $7(3.1 \%)$ & $1(0.5 \%)$ \\
\hline Poor & $27(11.9 \%)$ & $15(7.5 \%)$ \\
\hline Average & $108(47.6 \%)$ & $107(53.2 \%)$ \\
\hline Good & $76(33.5 \%)$ & $74(36.8 \%)$ \\
\hline Very good & $9(3.9 \%)$ & $4(2.0 \%)$ \\
\hline
\end{tabular}

recommended frequency of $\mathrm{BC}$ screening accounted for $16.7 \%$ and $10.0 \%$ of laywomen and screening attendees, respectively. Associated factors of knowing the right answers are listed in Table 2.

\section{Breast self-examination (BSE)}

The recommended age of first BSE (that is, 20 years of age) was rightly recognized in $38.8 \%$ and $51.2 \%$ by laywomen and screening attendees, respectively (Fig. 1). 
Table 2 Significant associated factors of respondents' knowledge of BC screening, BSE and BC

\begin{tabular}{|c|c|c|c|c|}
\hline \multirow[t]{2}{*}{ Outcome } & \multicolumn{2}{|l|}{ Laywomen } & \multicolumn{2}{|c|}{ Screening attendees } \\
\hline & Predictive factors & Effect & Predictive factors & Effect \\
\hline $\begin{array}{l}\text { Knowing the recommended age } \\
\text { of first } B C \text { screening and the } \\
\text { frequency of } B C \text { screening }\end{array}$ & Age & $\begin{array}{l}(B=0.039 ; p=0.026 ; O R=1.040 \\
95 \% C l 1.005-1.076)\end{array}$ & NS & \\
\hline $\begin{array}{l}\text { Knowing the recommended age } \\
\text { of first BSE and the frequency } \\
\text { of BSE }\end{array}$ & Education & $\begin{array}{l}(B=0.386 ; p=0.016 ; O R=1.472 \\
95 \% C l 1.076-2.013)\end{array}$ & NS & \\
\hline \multirow[t]{2}{*}{$\begin{array}{l}\text { Knowing that } \mathrm{BC} \text { is a common } \\
\text { cause of death in Hungary }\end{array}$} & Age & $\begin{array}{l}(B=0.029 ; p=0.034 ; O R=1.030 \\
95 \% \text { Cl } 1.090-1.058)\end{array}$ & NS & \\
\hline & Education & $\begin{array}{l}(B=0.279 ; p=0.014 ; O R=1.322 \\
95 \% C l 1.059-1.651)\end{array}$ & NS & \\
\hline \multirow[t]{3}{*}{$\begin{array}{l}\text { Knowing that there is an asympto- } \\
\text { matic period of early BC }\end{array}$} & Age & $\begin{array}{l}(B=0.033 ; p=0.043 ; O R=1.033 \\
95 \% C l 1.001-1.067)\end{array}$ & Age & $\begin{array}{l}(B=0.046 ; p=0.032 ; O R=1.047 \\
95 \% C l 1.004-1.093)\end{array}$ \\
\hline & Education & $\begin{array}{l}(B=1.057 ; p=0.028 ; O R=1.985 \\
95 \% \mathrm{Cl} 1.090-3.615)\end{array}$ & Education & $\begin{array}{l}(B=0.395 ; p=0.015 ; O R=1.485 \\
95 \% C l 1.080-2.041)\end{array}$ \\
\hline & $\begin{array}{l}\text { Place of residency } \\
\text { (county town vs. } \\
\text { village) }\end{array}$ & \multicolumn{2}{|l|}{$\begin{array}{l}(B=0.577 ; p<0.001 ; O R=1.78095 \% \text { NS } \\
C l 1.342-2.360)\end{array}$} & \\
\hline $\begin{array}{l}\text { Being well-informed about } \\
\text { symptoms }\end{array}$ & Education & $\begin{array}{l}(B=0.493 ; p=0.001 ; O R=1.638 \\
95 \% C l 1.213-2.211)\end{array}$ & Education & $\begin{array}{l}(B=0.353 ; p=0.012 ; O R=1.424 \\
95 \% C l 1.081-1.876)\end{array}$ \\
\hline
\end{tabular}

All outcomes are adjusted for age, education and residency

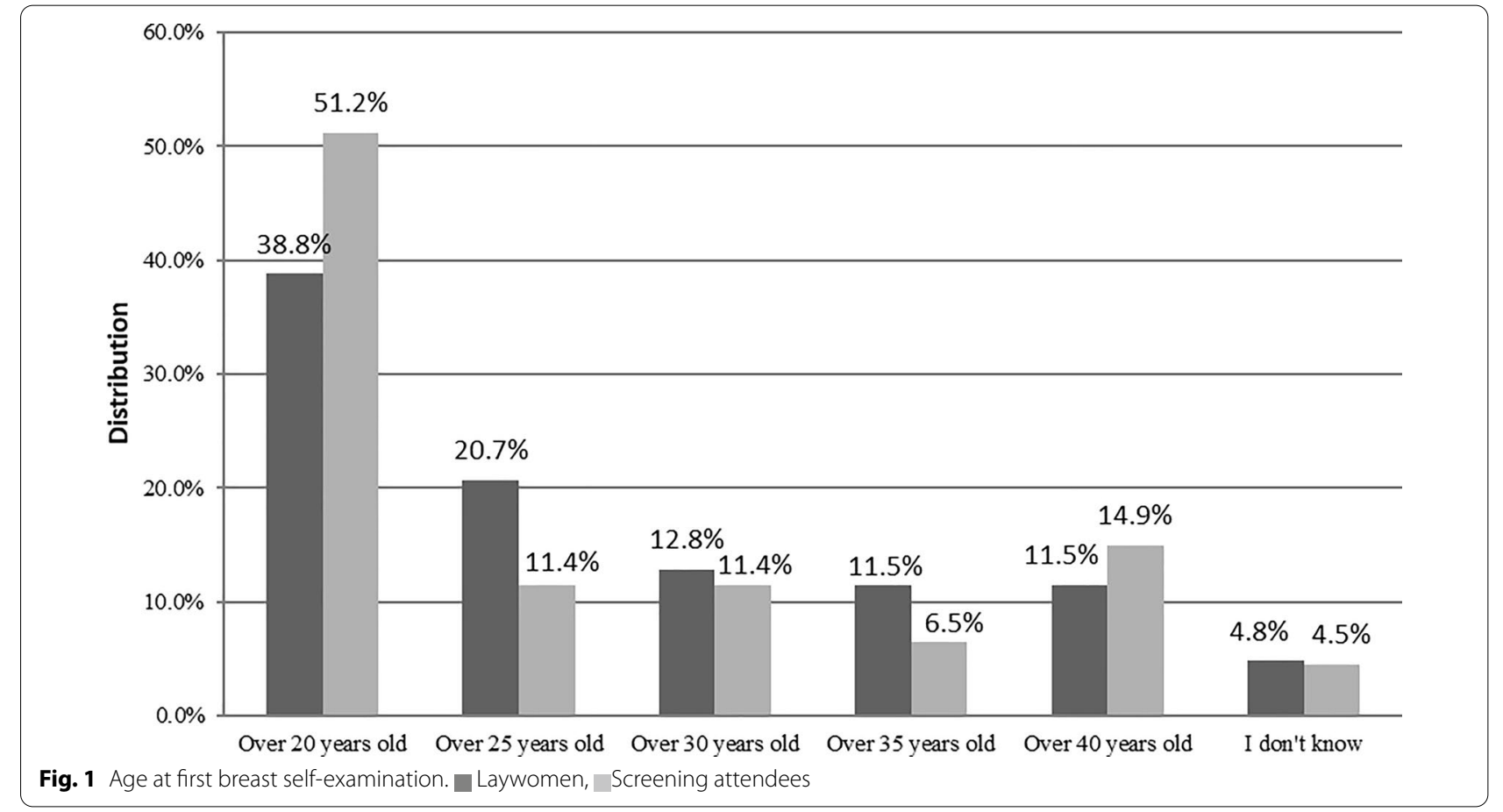

The recommended timing of BSE (that is, at the weekend following period) was identified correctly in $32.2 \%$ and $31.8 \%$ by laywomen and screening attendees, respectively; without a significant difference between screening attendees and laywomen of screening age without attending for $\mathrm{BC}$ screening in the past 2 years (Fig. 2). Respondents who knew both the recommended age of first BSE and the recommended timing of BSE accounted for $13.7 \%$ and $18.4 \%$ of laywomen and 


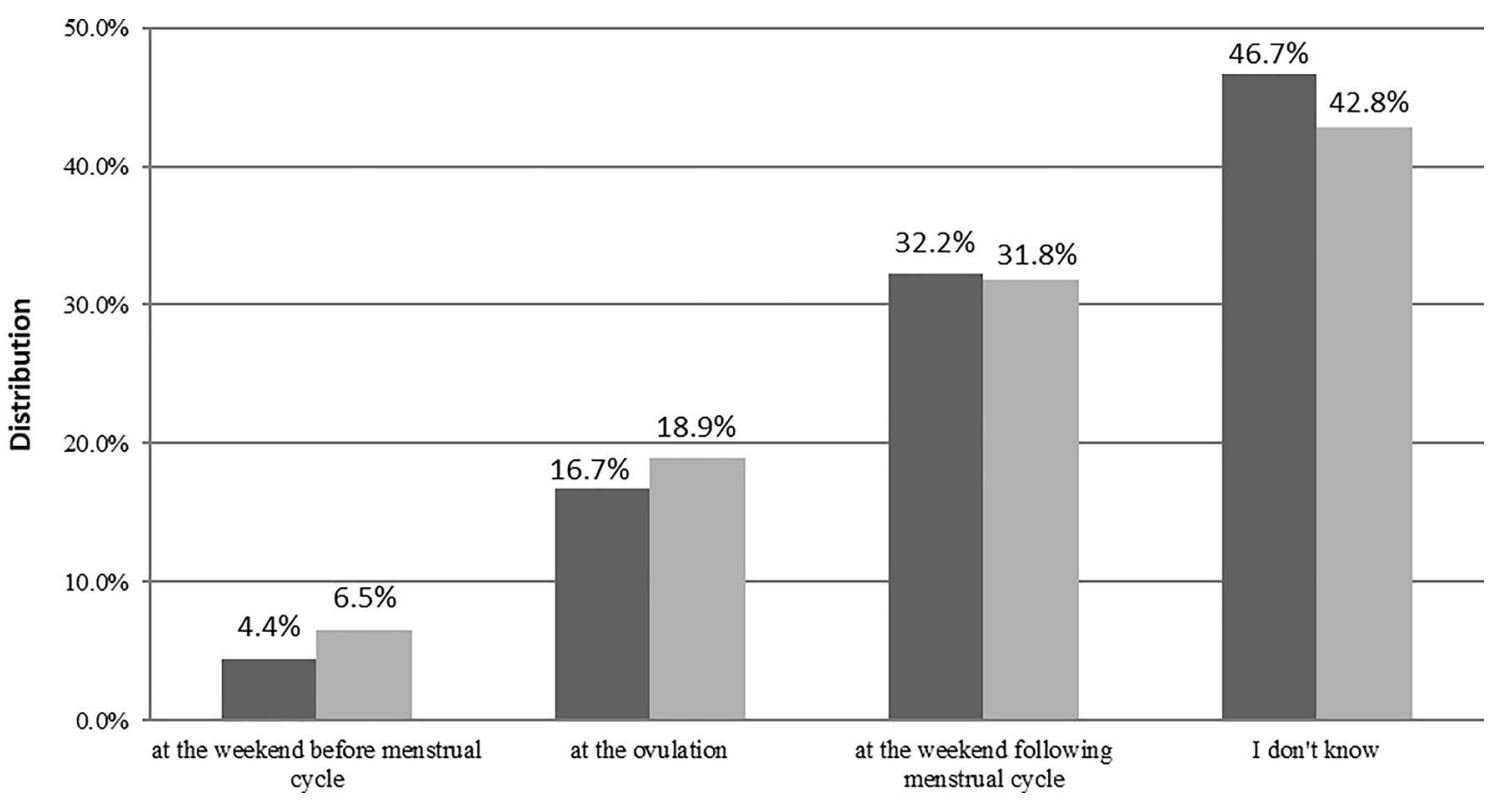

Fig. 2 Timing of breast self-examination. Laywomen, 1 Screening attendees

screening attendees, respectively. Associated factors of knowing the right answers are listed in Table 2.

\section{Curability and mortality of $\mathrm{BC}$}

The majority of laywomen believed that early $\mathrm{BC}$ can be curable $(92.5 \%)$, the ratio was similar among screening attendees (96.5\%).

Laywomen and screening attendees stated that $\mathrm{BC}$ is a common cause of death in Hungary in $68.8 \%$ and $76.6 \%$ respectively. Associated factors of knowing the right answers are listed in Table 2.

\section{Signs and symptoms of $B C$}

An early BC can be asymptomatic according to $80.6 \%$ and $78.1 \%$ of laywomen and screening attendees, respectively.

$16.7 \%$ and $28.9 \%$ of laywomen and screening attendees had sufficient knowledge of symptoms, respectively. Agreement on the 3 most common symptoms was good between groups: lumps (95.2\% and $93.0 \%$ ), axillary nodes (75.8\% and $73.1 \%$ ), and bloody discharge of mamilla (49.3\% and $53.2 \%)$ were indicated by laywomen and screening attendees, respectively (Fig. 3). Associated factors of having sufficient knowledge are listed in Table 2.

\section{Risk factors of $B C$}

The majority of both laywomen and screening attendees had sufficient knowledge of risk factors of BC (7.0\% vs. $6.0 \%$, respectively). Laywomen believed that genetic predisposition (81.1\%), physical trauma (55.5\%), and smoking $(47.1 \%)$ are the three most common risk factors, whereas screening attendees favored to choose genetic predisposition (85.6\%), physical trauma (49.3\%), and irradiation (45.8\%). The data did not satisfy the conditions of logistic regression model because only a small proportion of the respondents had sufficient knowledge of risk factors so that we analysed this outcome with univariate statistics exclusively. Among screening attendees, women who had sufficient knowledge were better educated $(p=0.01)$.

\section{Source of information}

Television (41.9\%), the internet (41.0\%), and general practitioners or specialists $(38.3 \%)$ were the three most common information sources among laywomen. On the contrary, screening attendees favored to choose general practitioners or specialists $(44.3 \%)$, friends and colleagues $(42.8 \%)$, and television $(37.8 \%)$ to be the three most common sources (Fig. 4).

\section{Discussion}

This study aimed to assess the knowledge of women (laywomen vs. screening attendees) of $\mathrm{BC}$ and $\mathrm{BC}$ screening. Since screening uptake is suboptimal in Hungary, an improvement would be desirable to reduce BC-related mortality. One potential tool for increasing awareness would be the initiation of public health interventions.

As we expected, there was a prominent difference between groups in knowing the recommended age at first BC screening: the ratio of correct answers favored screening attendees over laywomen of screening age not 

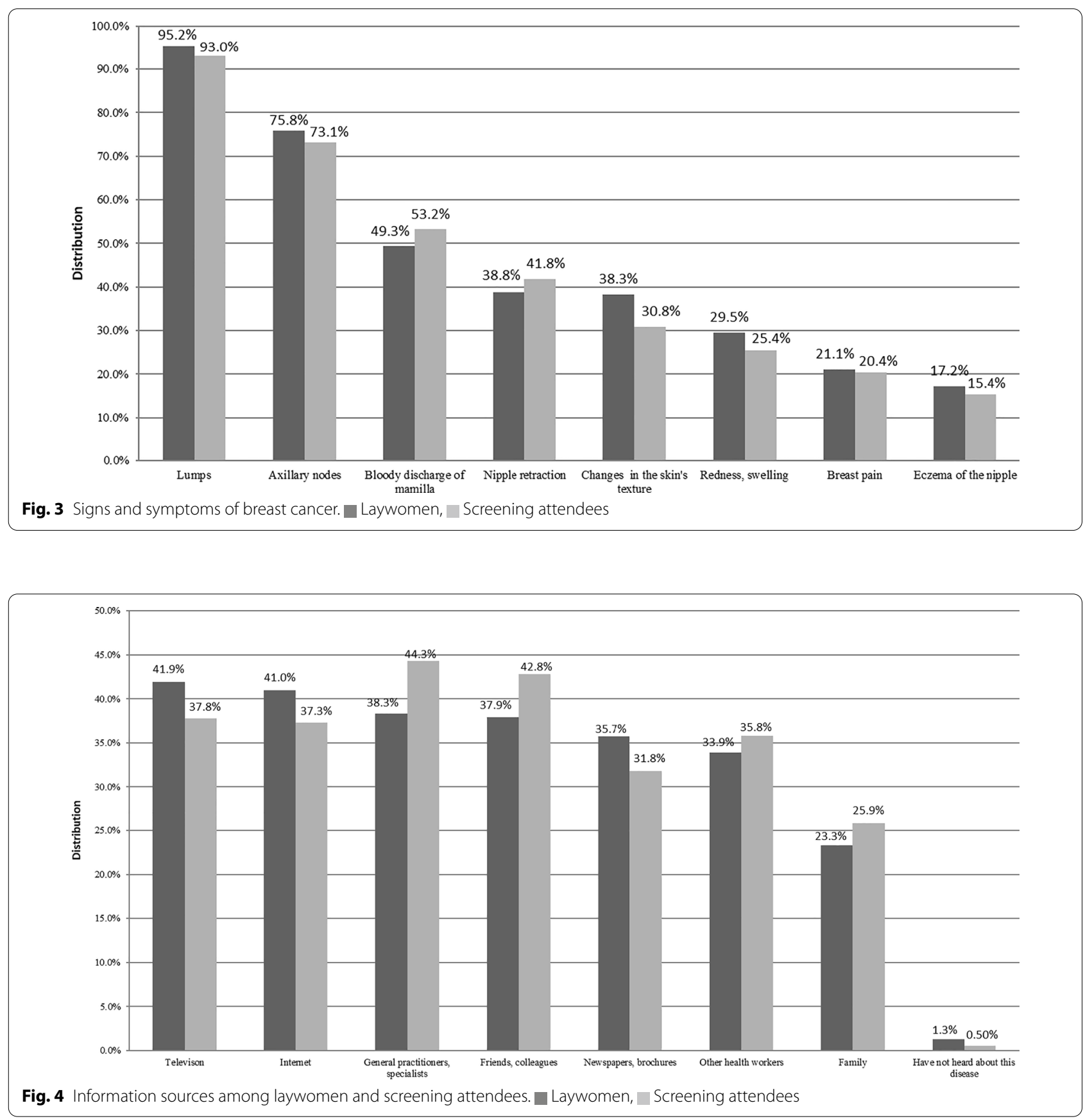

attending for BC screening in the past 2 years $(86.6 \%$ vs. $35.2 \%$, respectively). This might be attributed to the invitation letters for $\mathrm{BC}$ screening when reaching the appropriate age of screening (i.e., 45 years in Hungary) [15]. The difference between groups highlights the efficacy of population-based invitation letters for mass screening, even if the entire target population is not covered (around $80 \%$ ). However, we failed to detect a similar difference regarding the recommended frequency of $\mathrm{BC}$ screening; here, the ratio of correct answers was extremely low in both groups. The importance of screening is highlighted by the fact that the 5-year relative survival rate of stage III BC is about $72 \%$, women in this stage can often be treated successfully. On the contrary, stage IV (metastatic) $\mathrm{BC}$ has a 5 -year relative survival rate of about $22 \%$ [21]. Knowledge of BC screening protocol, particularly for those reaching the recommended age at first screening, should be improved. Among laywomen, respondents 
who had sufficient knowledge were older, which highlights the importance of education of the younger generation. The required information may be transmitted via the internet and the television for the younger women, and by family doctors and specialists or by distribution of flyers for the older women because our findings highlighted these as the most frequently chosen information sources.

Although BSE should be started more than two decades earlier than mammography (20 years vs. 45 years, respectively), most respondents were unaware of this. These results corroborate the findings of the study of Do Thi Thanh Toan et al. from North-Vietnam, in which only $19.3 \%$ of the respondents knew when to perform the first BSE [22]. Knowledge of screening attendees was not better significantly compared to that of laywomen of screening age not attending for $\mathrm{BC}$ screening in the past two years; this is true concerning the timing of regular BSE (i.e., at the weekend following period) as well. Although physical examination has a low sensitivity (54\%), its specificity is high (94\%) [23] and seems more relevant for women aged $40-49$ years than those aged above 50 years [24]. Laywomen with better education were more likely to know the recommended age of first BSE and the recommended timing of BSE. Since our findings were disappointing regarding BSE, it would be important to include the most important features of this screening modality (i.e., technique, timing in the period, and from what age) in the sexual education program of primary schools. This preventive activity may facilitate the early recognition of BC.

More than $90 \%$ of respondents had sufficient knowledge of the curability of early BC. In a study from Beirut, respondents had severe knowledge gaps regarding curability but were well informed about signs and symptoms [25]. A Mongolian study resulted in results comparable to ours: $91.1 \%$ of respondents knew that early recognition of $B C$ could improve survival [26]. On the contrary, only about $70 \%$ of the respondents knew that $\mathrm{BC}$ is a common cause of death. In Hungary, BC is the most common malignant tumor and the third most common cause of tumor-related mortality among women [1, 2]. Higher education and older age seem to be associated with better knowledge in laywomen.

About $80 \%$ of respondents knew that BC can be asymptomatic. However, both laywomen and screening attendees had insufficient knowledge of the typical clinical presentation: less than one-fourth of the respondents proved to have sufficient knowledge of signs and symptoms of BC. It would be important to extend women's knowledge of this aspect because recognizing signs and symptoms is a key moment in the detection and effective therapy of early BC. Literature states that the common signs and symptoms are lumps, mastitis, breast pain, and mamillar discharge [27]. The answers of respondents from the groups partly overlap: lumps were indicated by almost all respondents, whereas only half of them indicated mamillar discharge. Moreover, more than $70 \%$ indicated that axillary nodes belong to common symptoms while lymphatic metastases are rather characteristic of advanced $\mathrm{BC}$. It is important to highlight that the third most frequently indicated symptom was the bloody nipple discharge, indicated approximately by half of the respondents in both groups. In the study of Linsell et al. from the UK, most women (85\%) knew that lumps and axillary nodes could be the signs of $\mathrm{BC}$, but less than half of respondents knew that $\mathrm{BC}$ could be associated with non-nodular signs as well [28]. The attendance rate of mammography can be increased only if women are aware of the warning signs and symptoms of $\mathrm{BC}$; otherwise, they remain unrecognized and women will not see the doctor. Again, higher education, older age, living in county town were amenities, as demonstrated concerning signs and symptoms. According to a report, a positive family history for $\mathrm{BC}$ is associated with better knowledge (Western Turkey; 2011) [29]. According to our survey, BC among friends proved to be an associated factor of correctly knowing the frequency of $\mathrm{BC}$.

A dramatically insufficient knowledge was explored regarding the risk factors of $\mathrm{BC}$ : less than $10 \%$ of respondents had sufficient knowledge. Opposing to the low knowledge in the Hungarian cohort of subjects, Trupe et al. demonstrated that about one-third (31.3\%) of respondents had sufficient knowledge of risk factors of BC (in South African women aged 18-68 years; 2017) [30]. In our survey, both laywomen and screening attendees chose the same answers to be the two most common risk factors: genetic predisposition $(81.1 \%$ vs. $85.6 \%$, respectively) and physical trauma $(55.5 \%$ vs. $49.3 \%$, respectively). Discrepant answers were given regarding the third most common factor: laywomen favored smoking (47.1\%), whereas screening attendees favored irradiation (47.1\%). In an Indian study, respondents listed smoking and alcohol consumption as risk factors of $\mathrm{BC}$, but many respondents highlighted the importance of positive family history for $\mathrm{BC}$ [31]. The role of genetics and irradiation was overestimated by the respondents: in fact, genetic predisposition is responsible only for around $5-10 \%$ of all $\mathrm{BC}$ cases, the most common association is with the mutations of BRCA genes [11]. Most respondents were misinformed about the role of physical trauma: it has not been proven without doubt that trauma increases the risk of BC [32]. Screening attendees who had sufficient knowledge were significantly better educated. 
The most popular information sources were television and the internet among laywomen, whereas screening attendees favored general practitioners or other specialists, and colleagues or friends. Among adult Nigerian women (2014), the most common sources of information were the media and health care workers [33]. According to the survey of Maloney EK et al., laywomen preferred the internet to doctors to gather information about BC screening. Respondents frequently searched for information from the websites of cancer organizations about alternative therapies, adverse effects of therapies, conventional therapies, and traditional therapies (in Americans aged 27-79 years; 2015) [34]. Although the reliability and credibility of websites are questionable and often misleading, it is rare that patients, or at least their relatives, do not search for information about $\mathrm{BC}$ on the internet. The discrepant information sources between groups may explain the differences in the answers to the questions related to screening protocol and clinical phenotype of $\mathrm{BC}$.

\section{Limitations}

Cross-sectional surveys do not permit causal generalizations. Another limitation of the study is the nonprobability sampling used, raising concerns about self-selection bias.

\section{Conclusions}

Our results revealed that Hungarian women including laywomen and, unexpectedly, screening attendees are often mis- and underinformed about the risk factors as well as about the signs and symptoms of BC. Most laywomen are lacking knowledge of screening protocol. These findings urge for immediate $\mathrm{BC}$ screening and breast health knowledge intervention to increase knowledge among people, especially in the younger and less educated strata of society and villagers. Since electronic media (among laywomen) and healthcare workers (among screening attendees) are the major information sources, distribution of reliable and easily digestible information via these channels may improve knowledge, therefore improving awareness of BC screening. Our findings implicate that additional education may be recommended for BC screening attendees.

\section{Supplementary information}

The online version contains supplementary material available at https://doi. org/10.1186/s12905-021-01204-9.

Additional file 1: Questionnaire.
Abbreviations

BC: Breast cancer; OR: Odds ratios; Cl: Confidence intervals; BSE: Breast self-examination.

\section{Acknowledgements}

Authors would like to thank all general practitioners and medical assistants for their participation in the survey.

\section{Authors' contributions}

The study was designed by DK, GN, and IK. DK, GN, and ZS took part in the acquisition of data and performed statistical analyses. DK prepared the draft of the paper. IK supervised the study, participated in the interpretation of the data, and drafted the manuscript. All authors read and approved the final manuscript.

\section{Funding}

This study was funded by "GINOP-2.3.2-15-2016-00048-STAY ALIVE" co-financed by the European Union (European Regional Development Fund) within the framework of Programme Széchenyi 2020, and by Human Resources Development Operational Programme Grant, Grant Number: EFOP 3.6.2-16-2017-00006-LIVE LONGER which is co-financed by the European Union (European Regional Development Fund) within the framework of Programme Széchenyi 2020. The funders had no role in study design, data collection and analysis, decision to publish, or preparation of the manuscript.

\section{Availability of data and materials}

The datasets used and/or analysed during the current study are available from the corresponding author on request.

\section{Ethics approval and consent to participate}

Ethical approval was granted by the Regional and Institutional Ethical Committee of University of Pecs, Hungary (6542). Written informed consent was obtained from all participants.

\section{Consent to publication}

Not applicable.

\section{Competing interests}

The authors declare that they have no competing interests.

\section{Author details}

${ }^{1}$ Doctoral School of Health Sciences, University of Pécs, Pecs, Hungary.

${ }^{2}$ Institute for Translational Medicine, Medical School, University of Pécs, Szigeti út 12., 7624 Pecs, Hungary. ${ }^{3}$ János Szentágothai Research Center, University of Pécs, Pecs, Hungary. ${ }^{4}$ Department of Public Health Medicine, Medical School, University of Pécs, Pecs, Hungary.

Received: 14 June 2020 Accepted: 1 February 2021

Published online: 15 February 2021

\section{References}

1. The International Agency for Research on Cancer. GLOBOCAN 2018. France. http://globocan.iarc.fr. Accessed 9 Feb 2019.

2. National Institute of Oncology. http://www.onkol.hu/hu/rakregiszter-stati sztika. Accessed 9 Feb 2019

3. Li C, Beaber E, Mei-Tzu C, et al. Reproductive factors and risk of estrogen receptor positive, triple-negative, and HER2-neu overexpressing breast cancer among women 20-44 years of age. Breast Cancer Res Treat. 2013:137:579-87.

4. World Health Organization. http://www.who.int/Accessed. 2 Dec 2018

5. Reynolds P. Smoking and breast cancer. J Mammary Gland Biol Neoplasia. 2013;18(1):15-23.

6. Levine ME, Suarez JA, Brandhorst S, et al. Low protein intake is associated with a major reduction in IGF-1, cancer, and overall mortality in the 65 and younger but not older population. Cell Metab. 2014;19:407.

7. Kristin Rojas MD, Ashley Stuckey MD. Breast cancer epidemiology and risk factors. Clin Obstet Gynecol. 2016;59(4):651-72. 
8. Aisenberg C, Finkelstein D, Doppke K, et al. High risk of breast carcinoma after irradiation of young woman with Hodgkin's disease. Cancer. 1997;79:1203-10.

9. Swerdlow A, Barber J, Hudson G, et al. Risk of second malignancy after Hodgkins's disease in a collaborative British cohort: the relation to age treatment. J Clin Oncol. 2000;18:498-509.

10. Collaborative Group on Hormonal Factors in Breast Cancer. Breast cancer and breastfeeding: collaborative reanalysis of invidual data from 47 epidemiological studies in 30 countries, including 50302 woman with breast cancer and 96973 woman without disease. Lancet. 2002;360:187-95.

11. Economopoulou P, Dimitriadis G, Psyrri A. Beyond BRCA: new hereditary breast cancer susceptibility genes. Cancer Treat Rev. 2015;41(1):1-8.

12. Chen J, Silver D, Cantor S, et al. BRCA 1, BRCA2, and Rad51 operative in a common DNA damage response pathway. Cancer Res. 1999;59:1752-6.

13. Garber JE, Goldstein AM, Kantor AF, Dreyfus MG, Fraumeni JF, Li FP. Follow up study of twenty-four families with Li-Fraumeni syndrome. Cancer Res. 1991;5:6094-7.

14. Tan M-H, Mester JL, Ngeow J, Rybicki LA, Orloff MS. Charis Eng Lifetime cancer risks in individuals with germline PTEN mutations. Clin Cancer Res. 2012;18(2):400-7.

15. Lajos D. Daganatok szűrése minőségbiztosítási kézikönyv és módszertani útmutatóOrszágos Tisztifőorvosi Hivatal. Budapest. 2013;213:141-228.

16. IARC. Handbooks of cancer prevention. Breast cancer screening, vol. 7 . Lion: IARC; 2002.

17. https://www.cochrane.org/CD001877/BREASTCA_screening-for-breas t-cancer-with-mammography. Accessed 2 Dec 2018.

18. Zunzunegui RG, Chung MA, Oruwari J, et al. Casting-type calcifications with invasion and high-grade ductal carcinoma in situ a more aggressive disease? Arch Surg. 2003;138(5):537-40.

19. Giordano L, von Karsa L, Tomatis M, Majek O, de Wolf C, Lancucki L, et al. Mammographic screening programmes in Europe: organization, coverage and participation. J Med Screen. 2012;19:72-82.

20. Basu P, Ponti A, Anttila A, Ronco G, Senore C, Vale DB, et al. Status of implementation and organization of cancer screening in the European Union Member States - Summary results from the second European screening report. Int J Cancer. 2018;142:44-56.

21. https://www.cancer.org/cancer/breast-cancer/understanding-a-breas t-cancer-diagnosis/breast-cancer-survival-rates.htmlAccessed. 10 Dec 2018.

22. Toan DTT, Son DT, Hung LX, Minh LN, Mai DL, Hoat LN. Knowledge, attitude, and practice regarding breast cancer early detection among women in a mountainous area in Northern Vietnam. Cancer Control. 2019;26(1):1073274819863777.
23. Thistlethwaite J, Stewart RA. Clinical breast examination for asymptomatic women-exploring the evidence. Aust Fam Physician. 2007;36:145-50.

24. Hassan LM, Mahmoud N, Miller AB, Iraj H, Mohsen M, Majid J, Reza SM, Mojgan M. Evaluation of effect of self-examination and physical examination on breast cancer. Breast. 2015;24(4):487-90.

25. El Asmar M, Bechnak A, Fares J, Al Oweini D, Alrazim A, El Achkar A, Tamim H. Knowledge, attitudes and practices regarding breast cancer amongst lebanese females in Beirut. Asian Pac J Cancer Prev. 2018;19(3):625-31.

26. Yerramilli P, Dugee O, Enkhtuya P, Knaul FM, Demaio AR. Exploring knowledge, attitudes, and practices related to breast and cervical cancers in Mongolia: a national population-based survey. Oncologist. 2015;20(11):1266-73.

27. Salzman B, Fleegle S, Tully AS. Common breast problems. Am Fam Physician. 2012;86:343-9.

28. Linsell L, Burgess CC, Ramirez AJ. Breast cancer awareness among older women. Br J Cancer. 2008;99(8):1221-5.

29. Köşgeroğlu A, Ayrancı Ü, Özerdoğan N, et al. Knowledge of women on early diagnosis methods and risk factors for breast cancer in a province of Western Turkey: a descriptive study. Pak J Med Sci. 2011;27:646-50.

30. Trupe LA, Rositch A, Dickerson L, Lucas S, Harvey SC. Knowledge and attitudes about breast cancer in Limpopo, South Africa. J Glob Oncol. 2017;3(5):509-14.

31. Prusty RK, Begum S, Patil A, Naik DD, Pimple S, Mishra G. Knowledge of symptoms and risk factors of breast cancer among women: a community based study in a low socio-economic area of Mumbai, India. BMC Womens Health. 2020;20(1):106.

32. Rigby JE, Morris JA, Lavelle J, Stewart M, Gatrell AC. Can physical trauma cause breast cancer? Eur J Cancer Prev. 2002;11:307-11.

33. Olajide TO, Ugburo AO, Habeebu MO, Lawal AO, Afolayan MO, Mofikoya $\mathrm{MO}$. Awareness and practice of breast screening and its impact on early detection and presentation among breast cancer patients attending a clinic in Lagos, Nigeria. Nigerian J Clin Pract. 2014;17(6):802-7.

34. Maloney EK, D'Agostino TA, Heerdt A, Dickler M, Li Y, Ostroff JS, Bylund CL. Sources and types of online information that breast cancer patients read and discuss with their doctors. Palliat Support Care. 2015;13(2):107-14.

\section{Publisher's Note}

Springer Nature remains neutral with regard to jurisdictional claims in published maps and institutional affiliations.
Ready to submit your research? Choose BMC and benefit from:

- fast, convenient online submission

- thorough peer review by experienced researchers in your field

- rapid publication on acceptance

- support for research data, including large and complex data types

- gold Open Access which fosters wider collaboration and increased citations

- maximum visibility for your research: over $100 \mathrm{M}$ website views per year

At BMC, research is always in progress.

Learn more biomedcentral.com/submissions 